\title{
挙動・事象因果の定量的表現に基づく製品の不具合検出
}

\author{
明石 一希 ${ }^{* 1}$, 森永 英二*2, 若松 栄史 ${ }^{* 2}$, 倉橋 龍*1, 荒井 栄司 ${ }^{* 3}$
}

\section{Failure detection of products with quantitative modeling of behavior of entities and cause-and-effect relationships among physical phenomena}

\author{
Kazuki AKASHI ${ }^{* 1}$, Eiji MORINAGA ${ }^{* 2}$, Hidefumi WAKAMATSU², \\ Ryu KURAHASHI ${ }^{* 1}$ and Eiji ARAI ${ }^{* 3}$ \\ ${ }^{* 1,{ }^{*},{ }^{*} 3}$ Osaka University, Division of Materials and Manufacturing Science \\ 2-1 Yamadaoka, Suita-shi, Osaka 565-0871, Japan
}

Received: 28 February 2017; Revised: 25 August 2017; Accepted: 10 September 2017

\begin{abstract}
With recent globalization in industries, the number of failures and troubles of products caused by using them in unexpected ways has increased. In order to avoid such troubles, it is necessary not only to assume various ways of use thoroughly, but also to verify whether the design plan can fulfill required functions when the product is utilized in those ways. From this point of view, the authors proposed a functional verification method considering ways of use based on qualitative modeling of behavior of entities and cause-and-effect relationships among physical phenomena using Petri nets. It is, however, impossible to detect failures concerning to specification which requires dealing with quantitative information. This paper provides a method for quantitative modeling of behavior of entities and cause-and-effect relationships among physical phenomena. Two types of tokens were defined for dealing with positive and negative values and four types of arcs were for controlling changes of those values. These new elements of Petri net made it possible to represent behavior of entities and cause-and-effect relationships quantitatively. Application of this new modeling method to the functional detection method enables automatic detection of failures concerning to both functions and specification. The detection method using this modeling method was applied to an example, and its effectiveness was proven.
\end{abstract}

Key words : Failure detection, Quantitative modeling, Behavior, Cause-and-effect relationships, Petri net

\section{1. 緒言}

近年，グローバル市場への製品投入と生産拠点のグローバル化が多くの企業で進められている．また，同時に 消費者ニーズの多様化も進んでいる，これに伴い，想定外の使い方により，本来の要求機能が発現しない，好ま しくない現象が生じる，といった機能的不具合が発生している．そのため，個々の使い方に起因する機能的不具 合を設計段階で客観的かつ的確に検出して，設計の修正を促すような設計支援方法論の構築が求められている.

製品の不具合を事前に分析・把握する方法として, FTA（Fault Tree Analysis）(Lee et al., 1985）やFMEA（Failure Mode and Effects Analysis) (Rausand and Oien, 1996)が広く利用されている.しかし，故障事象や故障モードの設定 といった，分析結果に大きく影響する作業項目が，設計者の知識に強く依存しており，十分な経験を持つ設計者 でなければ，適切な分析を行うことが難しいという問題がある．また，逆に，熟練した設計者であっても，故障 事象や故障モードの設定とそれらの影響関係の記述において，自身の経験に囚われてしまい，分析漏れが生じる 可能性も考えられる. これらの属人性に関する問題の解決策が論じられている(村上，菊池，2009) (平岡，山本，

No.17-00084 [DOI:10.1299/transjsme.17-00084], J-STAGE Advance Publication date : 19 September, 2017

本論文は，第26回設計工学・システム部門講演会 講演論文集(2016), No.2216，および，Proceedings of Asia Design Engineering

Workshop(2016), No.7の掲載内容に基づいた論文である.

${ }^{* 1}$ 学生員, 大阪大学 大学院工学研究科 マテリアル生産科学専攻（†565-0871 大阪府吹田市山田丘 2-1）

$*_{2}$ 正員, 大阪大学

*3 正員, フェロー, 大阪大学

E-mail of corresponding author: kazuki.akashi@mapse.eng.osaka-u.ac.jp 
2011)ものの，十分な解決にはさらなる展開を待つ必要がある.

筆者らは, 実体の挙動のモデリングと分析を中心とする, 使い方を陽に考慮した機能検証の枠組みを提案して いる(Morinaga et al., 2015a). 実体の挙動，設計案に含まれる機能構造，使い方によって生じる物理事象間の因果 関係（事象因果）をグラフによってそれぞれモデル化し，ペトリネットへの変換を介してそれらを統合した後， 統合化されたペトリネット上での定性シミュレーションによって異常挙動を検出して，その機能的意味を分析す ることで，機能検証を行うものになっている，機能や事象因果のモデリングなどに知識依存の部分が残されてお り, 今後, 解決を図っていく必要があるものの, 実体の挙動という明確な情報のモデリングとシミュレーション を介したシステマティックな分析に基づいているという点で, 経験の多少に関わらず, 適切な検証が行える可能 性が高いと期待できる.この期待の下で, 挙動モデリングの改善(Morinaga et al., 2015b), 電子機器やセンサ搭載 製品への適用(Morinaga et al., 2014) (森永他，2016)などの拡張を進めてきている.

これらの一連の手法は, 機能面での不具合を検出の対象としているが，製品の不具合には属性值に関するもの も存在する. 製品設計では, 使用者の要求を満たすような製品仕様, 寸なわち, 製品の満たすべき目標值も設定 され，それが満たされるように設計が行われる．使い方によっては，この目標值が満たされなくなるという，仕 様に関する不具合も発生しうる．この不具合は，機能が発現していても，製品が目標值を満たさなければ生じる 可能性がある．例えば，「水を指定温度まで温める」という製品を考えたとき，「水を温める」機能が発現してい ても指定温度まで温めることができなければ製品としては不具合となる．したがって，製品の状態，および，そ の状態の属性值に着目することが重要となる. 先述した手法では, 状態の定性的な変化を捉え, モデル化するこ とは可能であるが，定量的な変化を表現することはできない，このため，仕様に関する不具合の検出に適用する ことができないという問題がある. 本稿では, 状態, 挙動, 事象因果の定量的な表現法を提案するとともに, 先 述した手法を機能的不具合だけではなく，仕様に関する不具合の検出にも適用できるように拡張する.

\section{2. 使い方を考慮した製品の不具合検出の枠組み}

製品の機能は, 実世界において製品の実体が示寸挙動を, 人間が主観的に評価し, 生成される抽象概念である と捉える考え方がある(冨山, 吉川, 1990). また, 製品がある使われ方をされると, それによって様々な物理事 象が生じ，それらが製品の実体の挙動に影響を与えることになる.これらの考察に基づくと，製品の使い方と製 品の機能は, 製品の挙動を介して間接的に関連していると解釈できる. したがって, 図 1 のように, 機能, 挙動, および, 使い方に依存して生起する事象群の因果関係を, それぞれモデル化し, それらを統合してできるモデル を分析することで，機能的不具合を検出することができる．この見解に基づいた，以下のような機能検証法が提 案されている(Morinaga et al., 2015a).

図 2 のように，ペトリネットのプレースを，製品あるいは部品がある属性值を有する状態に対応させ，そのプ レースにトークンが存在する場合に，その状態が真である，すなわち，製品あるいは部品が実際にその属性值を 有していると解釈することにすると, 状態の変化, 寸なわち挙動は, 図 3 のように, トランジション (図中の T0) の発火によるトークンの移動によって表現することができる. この図のプレース P0，P3 は，時間の経過を表す ため, 状態が関連づけられていないプレースであり, 以降ではタイミングのプレースと記述する. 機能は, 実体 の挙動を主観的に解釈して意味付けしたものであると考えられるため, その発現はトランジションの発火と関連 付けることができる. 寸なわち, トランジションの発火が, 機能の発現であると解棌できる. 一般に, ペトリネ ットにおけるトランジションの発火には条件が課されるため, 条件が満たされなくなれば, 機能は発現しなくな る. これが機能的不具合に相当する. この考えに基づき, 機能を機能分解木, 挙動と使い方に起因寸る事象因果 をペトリネットによってモデル化する. 次に, ペトリネットで表現された挙動モデルのトランジションを, 設計 者が機能に対応させることで機能モデルと挙動モデルとを統合し, さらに, 挙動モデルと事象因果モデルとを, 両者のモデル内の同一の状態を表すプレースを一体化することで統合する. これら 3 つのモデルが統合された統 合化モデル上で定性シミュレーションを行うことで, 起こりうる事象が挙動にどのように影響を与えるか, そし て, その挙動がどのような機能に対応しているかを確認でき, 使い方が製品機能にどのような影響を与えるのか を把握することができる. 
この従来手法は，ペトリネットのプレースを，製品あるいは部品がある属性值を有する状態に対応させるもの であって，属性值そのものをペトリネットで表現するものにはなっていない，例えば，図 4 のように，プレース P0 があり，その情報が図 4 の表のように情報が書かれているものとする。この図では，P0 にトークンが存在す

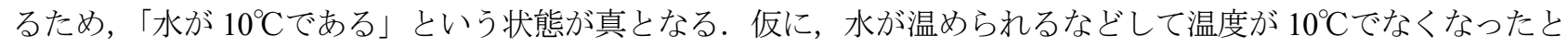

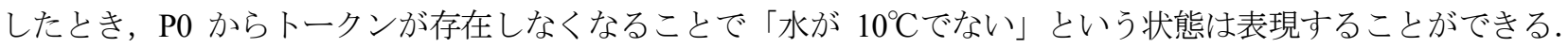
しかし，水が何 ${ }^{\circ} \mathrm{C}$ 変化するかどうかは，この図の表に情報が書かれていないため，確認することができない． したがって, 温度を確認するためには, 温度が変わるたびに表に書かれた属性值を書き換える必要があり, ペト リネットでのシミュレーションだけでは属性值の変化を確認できない，したがって，属性值に関連する仕様につ いての不具合を自動的に検出するためには，すなわち，属性值が所定の值に変化するかどうかをペトリネットで のシミュレーションにより確認するためには, 属性值自体をペトリネットで表現する必要がある.

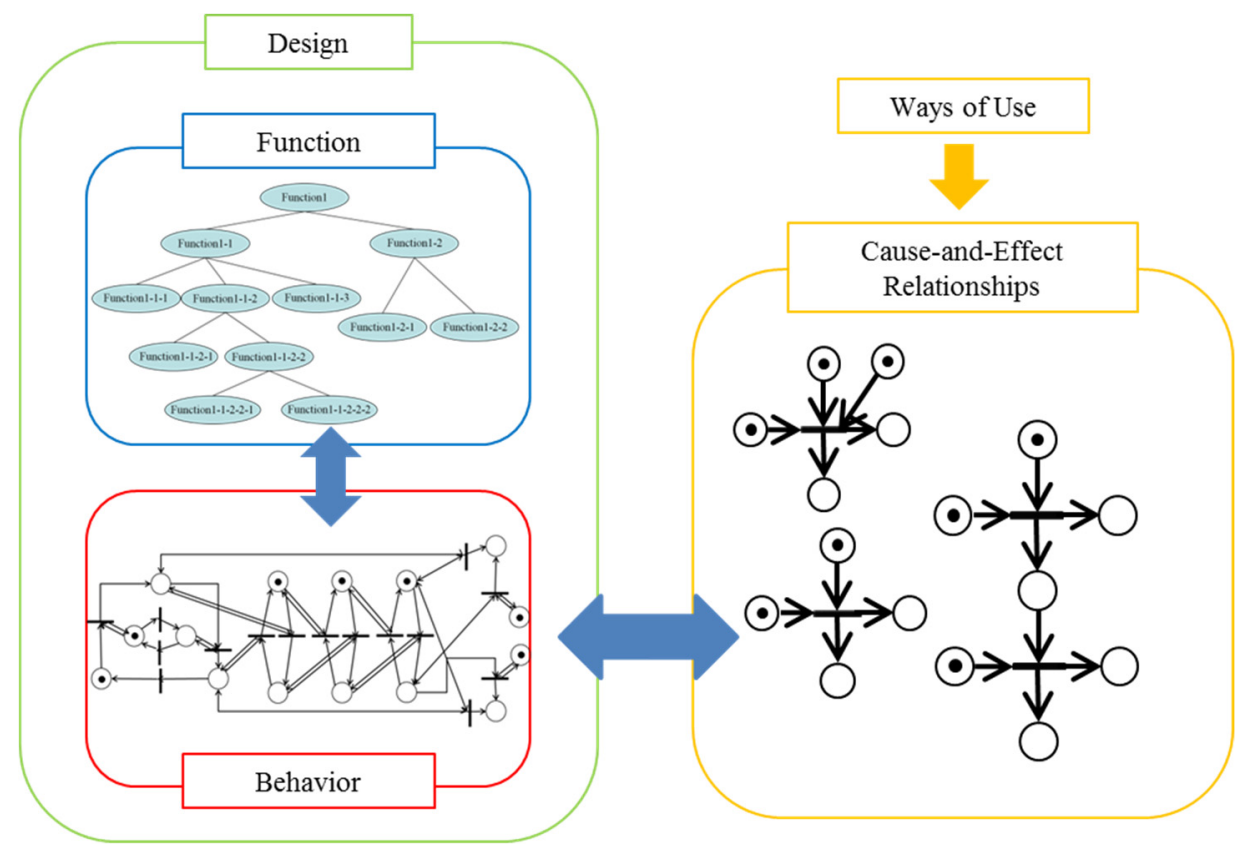

Fig. 1 Framework for analyzing functional failures caused by individual ways of use. Functional failures can be detected by modeling functions, behavior and cause-and-effect relationships among phenomena caused by the way of use and then analyzing the integrated Petri net model generated by merging those models.

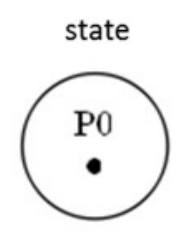

Fig. 2 Representation of state

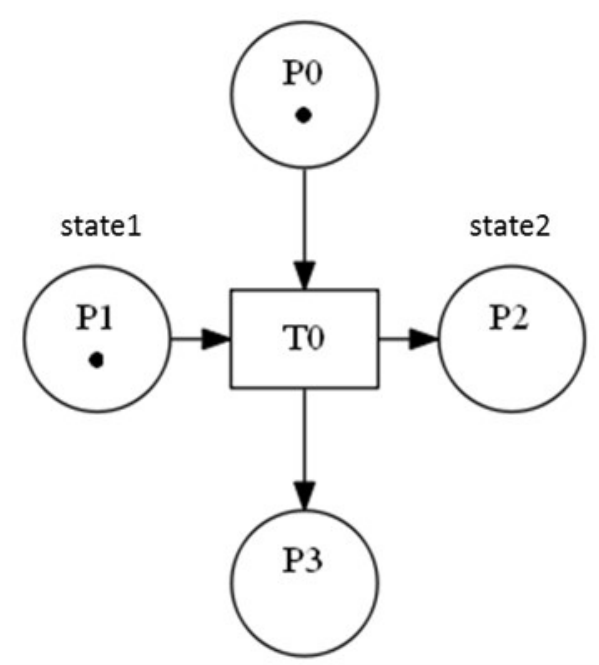

Fig. 3 Representation of behavior 

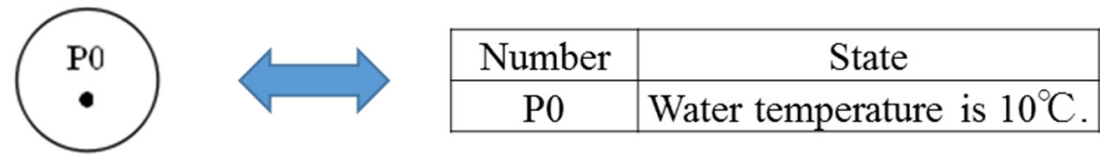

True

Fig. 4 Representation of state with quantitative information by conventional methods

\section{3. 状態・挙動 - 事象因果の定量的表現}

\section{$3 \cdot 1$ 状態の定量的表現}

状態の属性值をぺトリネットで表現するために，ペトリネットの構成要素であるトークンに值についての情報 を持たせることにする. 図 5 のように，○を正の值の情報を持つトークン，○を負の值の情報を持つトークンと 定義する．以降では，○を黒トークン，○を白トークンと記すことにし，それぞれの記号の後に書かれている数 字によって，プレースが持っている黒または白トークンの数を表すこととする．なお，プレースによっては，そ れが表す状態の属性值まで表現する必要がない場合があり，定性的な状態のみを表すプレースと，定量的な状態 を表すプレースとが混在することになる．このため，両者の区別がつくように，定量的な状態を表現するときに は，そのプレースを図 5 のように二重丸で表現することにする.

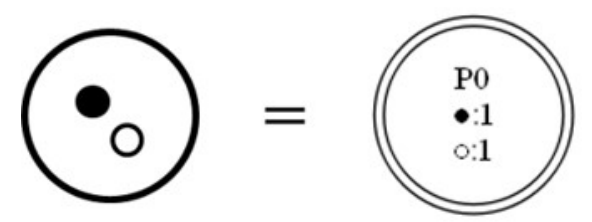

Fig. 5 Representation of states with quantitative information by black and white tokens

状態の属性值は，プレースが持つ黒トークンの数から白トークンの数を引いた值で表現することができる.し かし，図6に示すように，同一の属性值を表すことができる黒・白トークンの組合せは複数存在するため, 状態 を一意に表すことができない，そこで，図 7 のように，プレースが持つ黒，白トークンのいずれかの数を常に 1 とすることで，属性值を一意に表すことにする．この図では，プレース P1〜P5 は，それぞれ，-2，-1，0，1， 2 の值を表している.
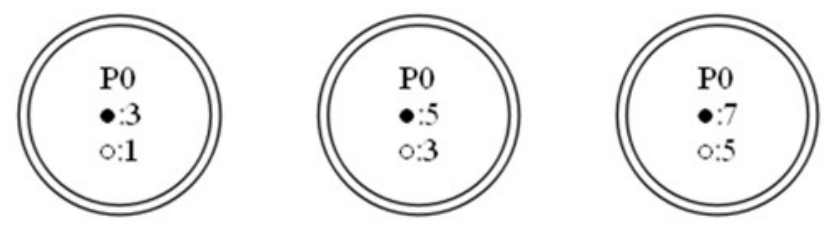

Fig. 6 Representation of state with the attribute value of 2
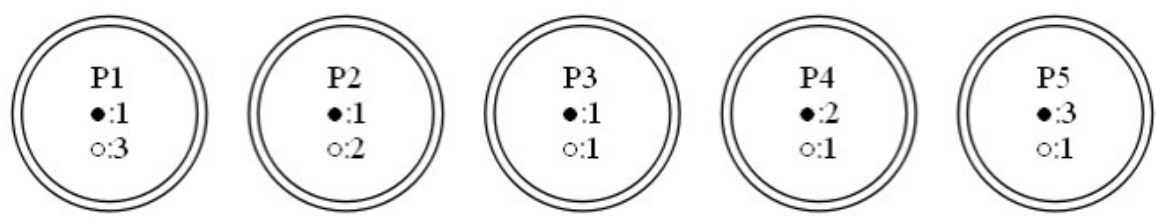

Fig. 7 Representation of various values by black and white tokens 


\section{$3 \cdot 2$ 挙動·事象因果の定量的表現}

ペトリネットに白トークンという新しい要素を導入したため，それがプレース間を移動するための仕組み，す なわち，トランジションの発火規則も新たに定める必要がある。そこで，図 8 のように，黒トークンの入出力を 司る黒アーク，白トークンの入出力を司る白アーク，黒トークンの数で発火を抑制する黒抑止アーク，白トーク ンの数で発火を抑制する白抑止アークの 4 種類のアークを新たに導入する. 黒, 白アークを用いて, プレース内 のアークと同色のトークンの数を変化させることで状態の属性值の加減を行うことができ，挙動の定量的表現が 可能となる．また，これら４つのアークを用いることで，状態の属性值をトランジションの発火条件に設定する ことができ，事象因果の定量的表現が可能となる.

(a) Black arc

(b) White arc

(c) Black inhibitor arc

(d) White inhibitor arc

Fig. 8 Type of arc

具体例として, 水の温度変化に関する挙動と事象因果の定量的表現の内容を以下に記す.水の温度が上昇する, 水が $100^{\circ} \mathrm{C}$ 皇ると沸騰する, 水が $0^{\circ} \mathrm{C}$ 以下になると凍るといった挙動・事象因果は, 図 9〜11 のように表せる. 図 9 の $\mathrm{P} 1$, 図 10 の $\mathrm{P} 4$, 図 11 の $\mathrm{P} 4$ が水の温度を表寸. また, 図 9 の $\mathrm{P} 0, \mathrm{P} 2$, 図 10 の $\mathrm{P} 0, \mathrm{P} 3$, 図 11 の $\mathrm{P} 0, \mathrm{P} 3$

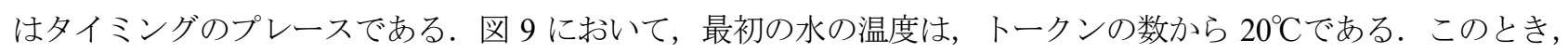
トランジション T0 が発火すると, P1 と T0 をつなぐ黒アークの重みが 10 であるため, P1 の黒トークンが 21 個 から 10 個増え， 31 個となり，水の温度が $20^{\circ} \mathrm{C}$ から $30^{\circ} \mathrm{C}$ に増加することになる. 図 10 の場合, $\mathrm{P} 4$ と $\mathrm{T} 0$ をつな ぐ黒アークの重みが 101 であるため, 黒トークンの数が 101 個以上, つまり水の温度が $100^{\circ} \mathrm{C}$ 以上のときに $\mathrm{T} 0$ が

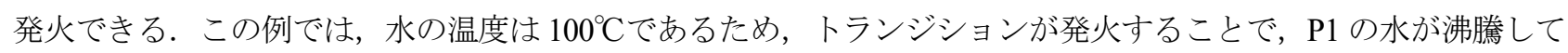
いない状態から，P2 の水が沸騰している状態になる. 図 11 の場合, P4 と $\mathrm{T} 0$ をつなぐ黒抑止アークの重みが 2 であるため, 黒トークンの数が 1 個以下，つまり水の温度が $0{ }^{\circ} \mathrm{C}$ 以下のときに $\mathrm{T} 0$ が発火できる. この例では，水

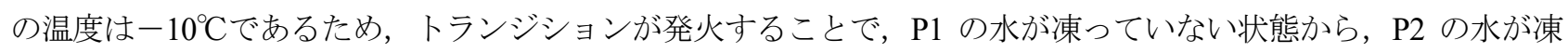
っている状態になる. このように, ペトリネットにおいて, 状態, 挙動, 事象因果の定量的な表現が可能になる.

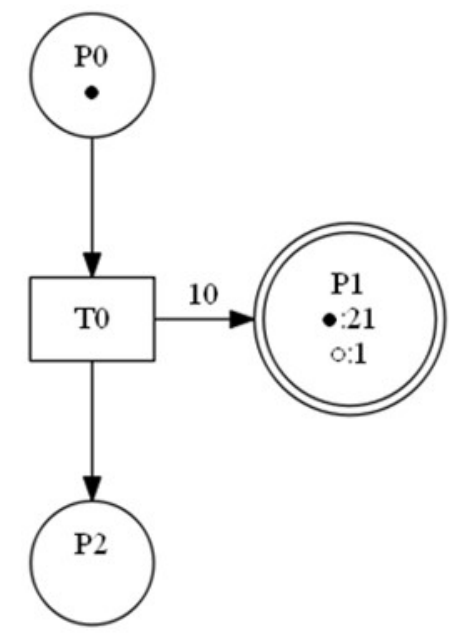

Fig. 9 Petri net model of increase of water temperature

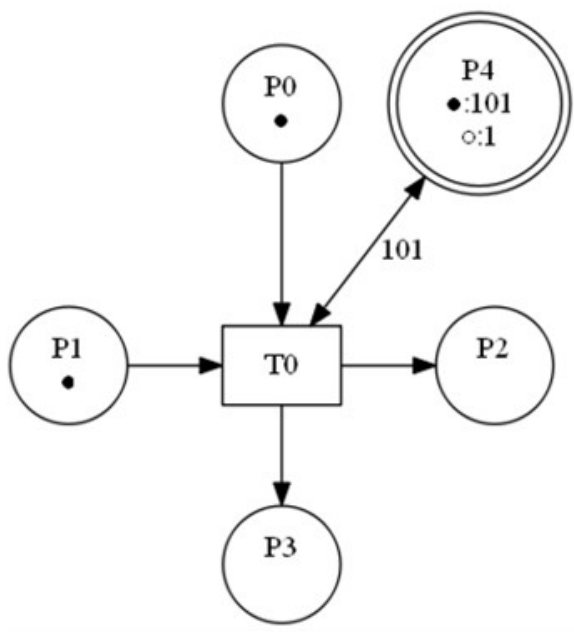

Fig. 10 Petri net model of boiling water 


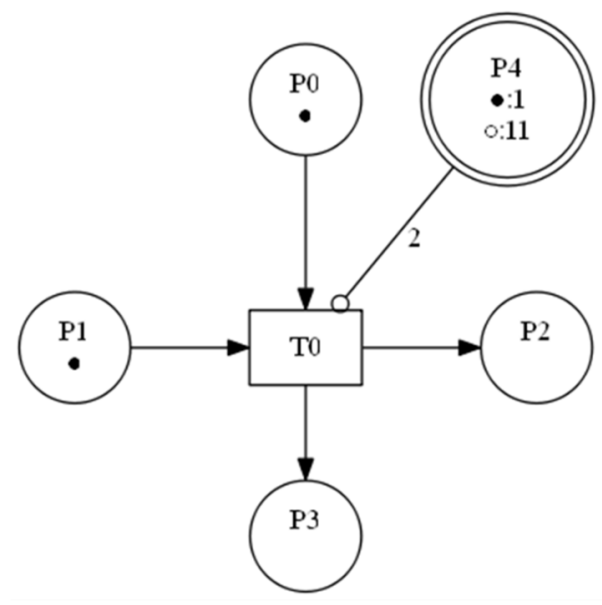

Fig. 11 Petri net model of freezing water

\section{$3 \cdot 3$ 状態の属性値によって変化する挙動・事象因果の表現}

状態の属性值をペトリネットの構成要素である黒トークンと白トークンの数で表現することにより，ペトリネ ット上でプレースの值を把握することが可能になる．これにより，プレースの值を参照することで，アークの重 みを動的に変化させることができる，このことを利用することで，状態の属性值によって変化する挙動・事象因 果の表現が可能になる．前節で示した，水が $100^{\circ} \mathrm{C}$ なると沸騰するという事象因果の例では，以下のようにな る.

一般に，水の沸点は気圧によって変化する．地上では $100^{\circ} \mathrm{C} て ゙$ 沸騰するが，標高の高い，すなわち気圧の低い

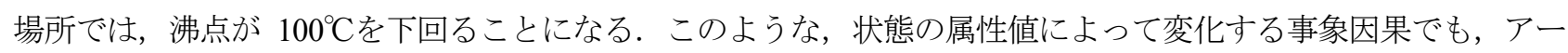
クの重みを動的に変化させることで表現することができる. まず, 図 12,13 に示すように, 水の沸騰を表したモ デル図 10 に対して, 標高を表すプレース P5 を新たに加える.さらに, P4 と T0 を結ぶアークの重みに, w = f(P5) という水の沸点と標高に関寸る重みの関数を与える. これは, アークの重みが標高である P5 の值によって変化 することを表す．これらにより，P5 の值によって，P4 と T0 を結ぶアークの重みを変化させ，T0 が発火できる 条件を変えることで, 水の沸点を変化させることができる. ここで, この重みの関数を簡単に, w = 101-P5/10 とする. 図 12 では, 地上の場合を表すことを考え，P5 の值を 0 とする. このとき，重みの関数から，アークの

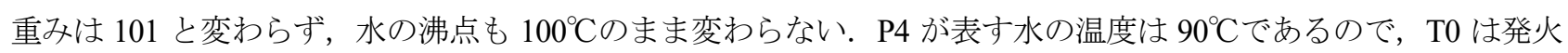
できず，水は沸騰していない状態のままとなる．図 13 では，標高の高い場所の場合を考え，P5 の值を 100 とす る.このとき, 重みの関数によって, アークの重みは 91 に減少し, 水の沸点も $100^{\circ} \mathrm{C}$ 次 $90^{\circ} \mathrm{C}$ ま減少する. $\mathrm{P} 4$ が表す水の温度は $90^{\circ} \mathrm{C}$ であるので, $\mathrm{T} 0$ は発火でき, 水は沸騰している状態に変化する. このように, アーク の重みに適当な関数を与えることで，水の沸点を P5 の值によって変化させることができる．以上のように，ア 一クの重みを動的に変化させることで, 状態の属性值によって変化する挙動・事象因果の表現が可能になる.

\section{4. ケーススタディ}

前章で提案した状態・挙動・事象因果の定量的表現法を従来手法に組み入れて計算機実装し，仕様に関する不 具合の事例に適用して，それを検出できるのかを確認した．天ぷら鍋の下に污れ防止マットを敷き，IH クッキン グヒーターで油を加熱したところ, 鍋が設定温度にならず，鍋の温度が上がりすぎて，油が発火した例を取り上 げる(独立行政法人国民生活センター, 2017). 提案手法に基づいて，このIH クッキングヒーターの挙動をモデル 化すると，図 14 のようなモデルが得られる．P1 が表す鍋の温度が $150^{\circ} \mathrm{C}$ 以上になるとき， T2 が発火し，トーク ンが P3 から P4 に移動して, 鍋が設定温度になっていない P3 の状態から, 鍋が設定温度になっている P4 の状態 になる. また, P6 はセンサーが正常に動作している状態を表しており, P0, P2, P5 はタイミングのプレースで

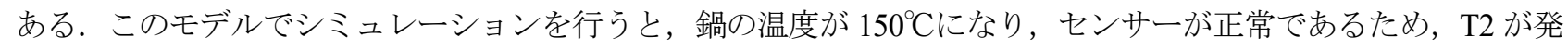
火し，設定温度になる．したがって，使い方に問題がなければ，問題なく設定温度になることが分かる. 


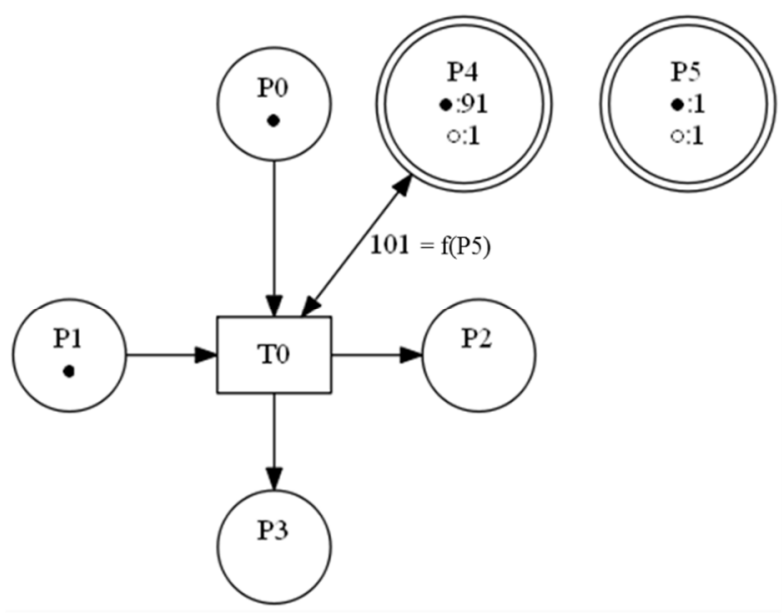

Fig. 12 Petri net model of boiling water at the ground level

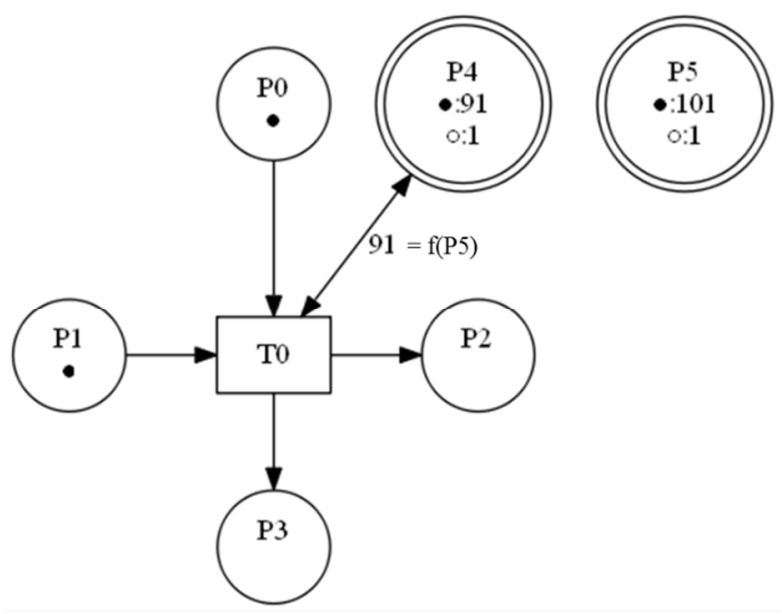

Fig. 13 Petri net model of boiling water in a place of high altitude

次に，使い方から生じる事象因果を考える，污れ防止マットを敷き，天ぷら鍋を加熱する使い方から生じる事 象因果は, 次の 5 つが挙げられる.

(1)＼cjkstart鍋の温度が上がると，マットの温度が上がる.

(2) マットの温度が上がると，マットが変形する.

(3) マッッが変形すると, 鍋とセンサーの距離が大きくなる.

(4)＼cjkstart鍋とセンサーの距離が一定以上になると，センサーが正常に動作しなくなる.

(5)＼cjkstart鍋の温度がある温度を超えると, 油が発火する.

上記(1)〜(5)の事象因果をひとつにまとめたモデルを作成し, それを図 15 に示す. P1 はマットの温度, P3 はマッ トの変化量，P5 は鍋とセンサーの距離，P6 は鍋の温度，P0，P2，P4，P7，P10，P11，P14 はタイミングのプレ 一スを表す．また，P6の值によって T0 と P1，P1 の值によって T1 と P3，P3 の值によって T2 と P5を結ぶアー クの重みを変化させることで, 鍋の温度によって, マットの温度が上昇し, それによりマットが変形し, その結 果, 鍋とセンサーの距離が大きくなることを表現している. また, P5 が表寸鍋とセンサーの距離の值が 5 以上の とき, T3 が発火し，センサーが正常に動作していない状態になることを表し，P6 が表す鍋の温度が $400^{\circ} \mathrm{C}$ 以上の とき, T4 が発火し, 油は発火している状態になることを表す.

図 14 の挙動モデルと図 15 の事象因果モデルで共通の情報をもつプレースを一体化することで, 図 16 で示され る統合モデルが，システムによって自動的に出力される．この図の P1 の鍋の温度，P6 のセンサーが正常に動作 している状態が一体化されたプレースである.この統合モデルにおいて, タイミングのプレース以外のプレース が持つ情報を表 1 に示す.

この統合モデル上でシミュレーションを行うと，途中の状態は図 17 のようになる. 鍋の温度が上がることで, マットの温度が上がる，そして，マットの変形が進み，鍋とセンサーの距離が大きくなる．その結果，センサー が正常に動作しなくなることが示されている.さらに，シミュレーションを進めると，最終的に図 18 のようにな る.この図から，センサーが正常に動作しなくなったことで，鍋の温度が設定温度を超えても上がり続け，油が 発火することが分かる．これにより，仕様に関する不具合が起きることを自動的に把握できる．したがって，「IH クッキングヒーターの挙動」,「污れ防止マットを敷き, 天ぷら鍋を加熱する使い方から生じる事象因果」をそれ ぞれシステムに入力することで,「油が発火する」という結果が出力される．これを設計者に示すことで, 製品の 取扱説明書に IH クッキングヒーターの上にマットを敷く使い方を禁止することや，敷いても問題がないような 機能を付加するといった対策を促し，設計支援につなげることができる. 


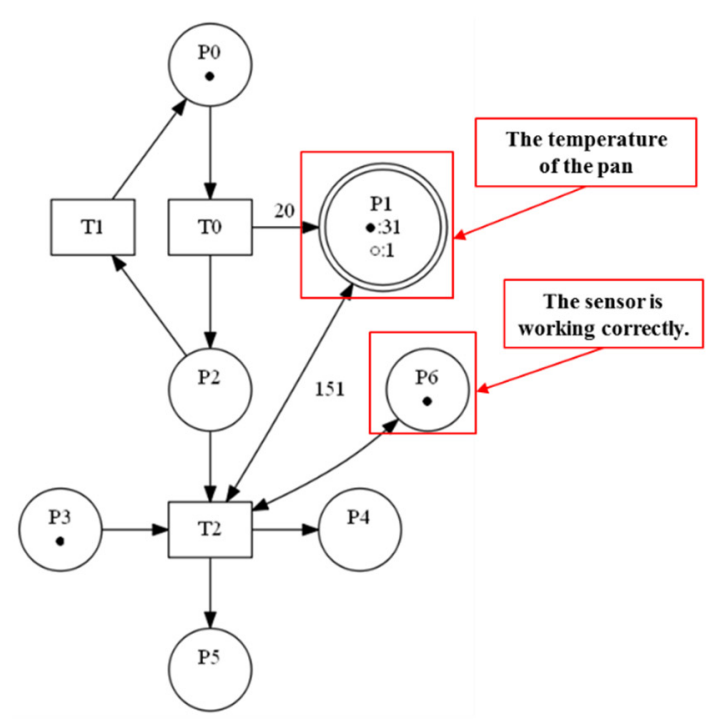

Fig. 14 Behavior model of IH cooking heater

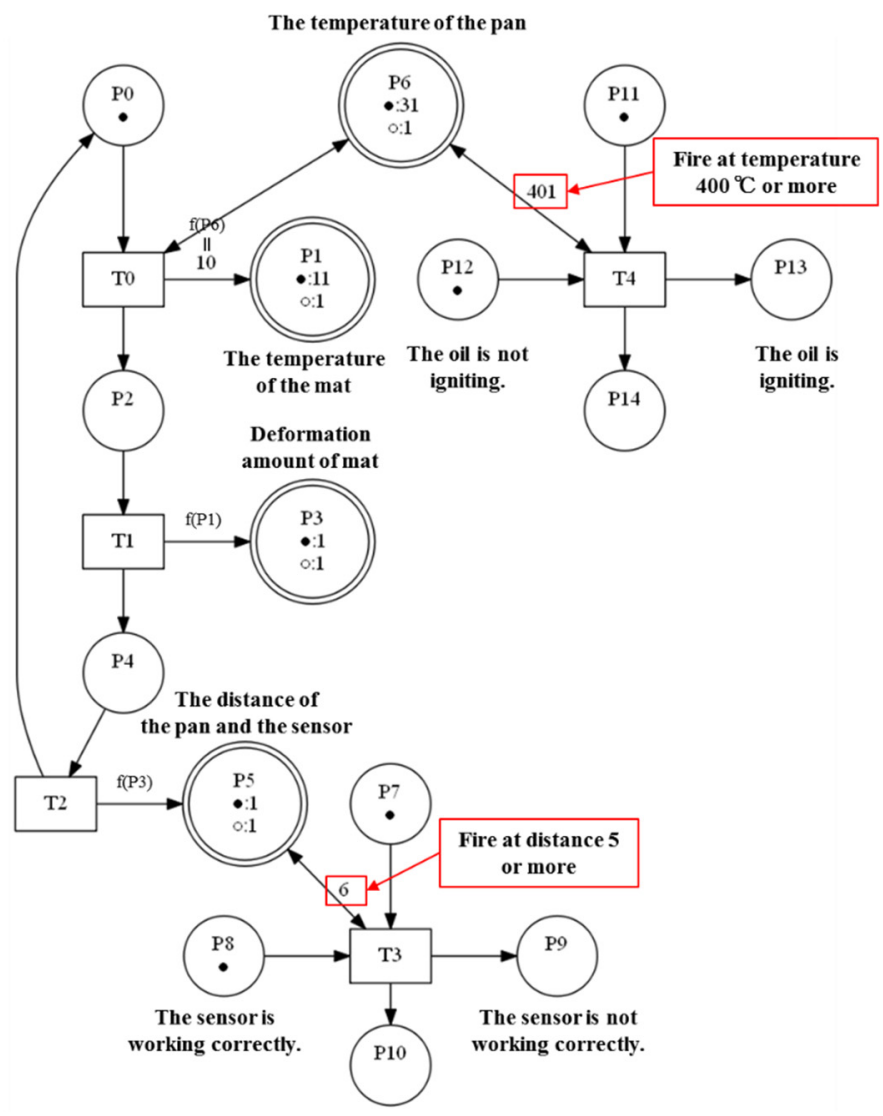

Fig. 15 Model of cause-and-effect relationships that occurs when putting the mat on the IH cooking heater

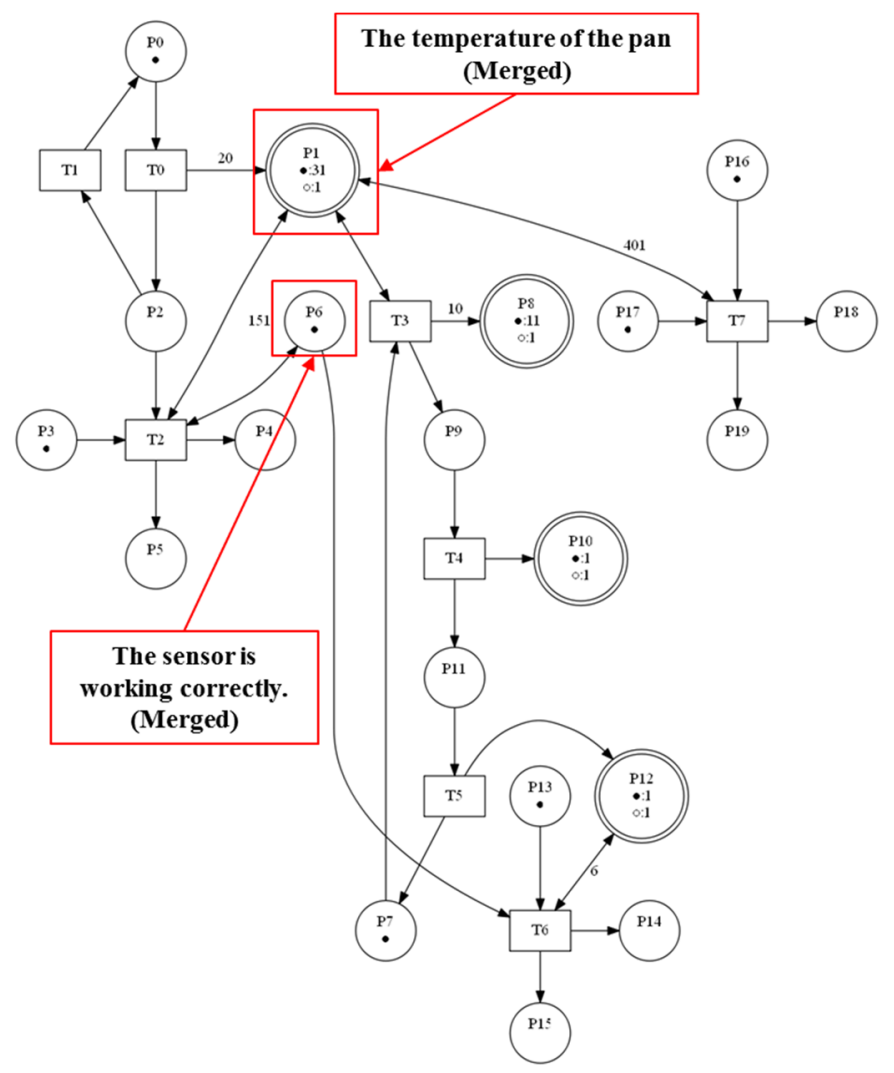

Fig. 16 Integrated model of IH cooking heater 
Table 1 Information of places in Fig. 16

\begin{tabular}{|c|c|}
\hline Number & State \\
\hline P1 & The temperature of the pan is $30^{\circ} \mathrm{C}$. \\
\hline P3 & The pan does not have preset temperature. \\
\hline P4 & The pan have preset temperature. \\
\hline P6 & The sensor is working correctly. \\
\hline P8 & The temperature of the pan is $10^{\circ} \mathrm{C}$. \\
\hline P10 & The deformation amount of mat is 0. \\
\hline P12 & The distance of the pan and the sensor is 0. \\
\hline P14 & The sensor is not working correctly. \\
\hline P17 & The oil is not igniting. \\
\hline P18 & The oil is igniting. \\
\hline
\end{tabular}

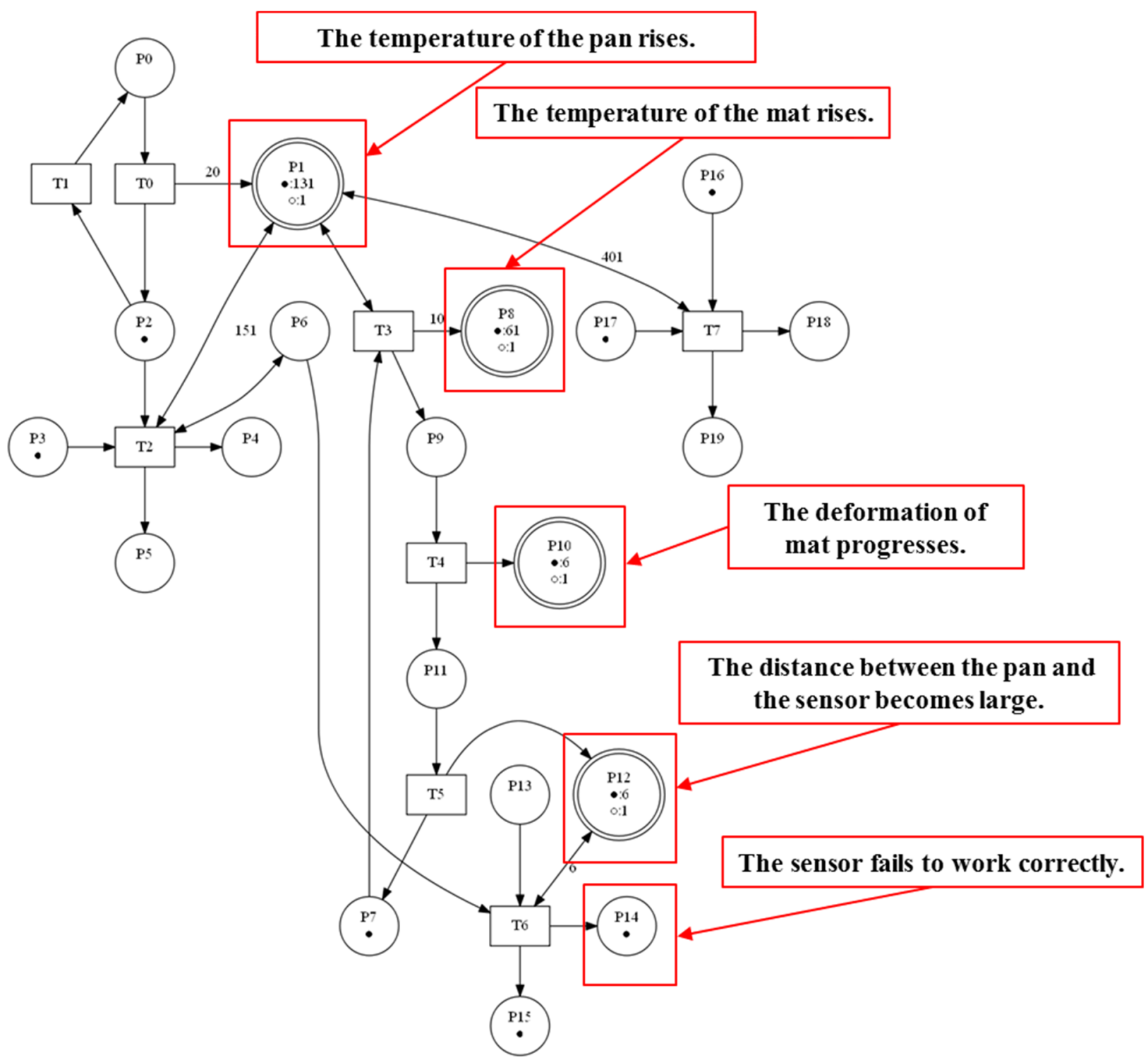

Fig. 17 Integrated model of IH cooking heater of the developmental state. As the temperature of the pan rises, the temperature of the mat rises. And the deformation of the mat progresses, the distance between the pan and the sensor become large. Thus, the sensor fails to work correctly. 


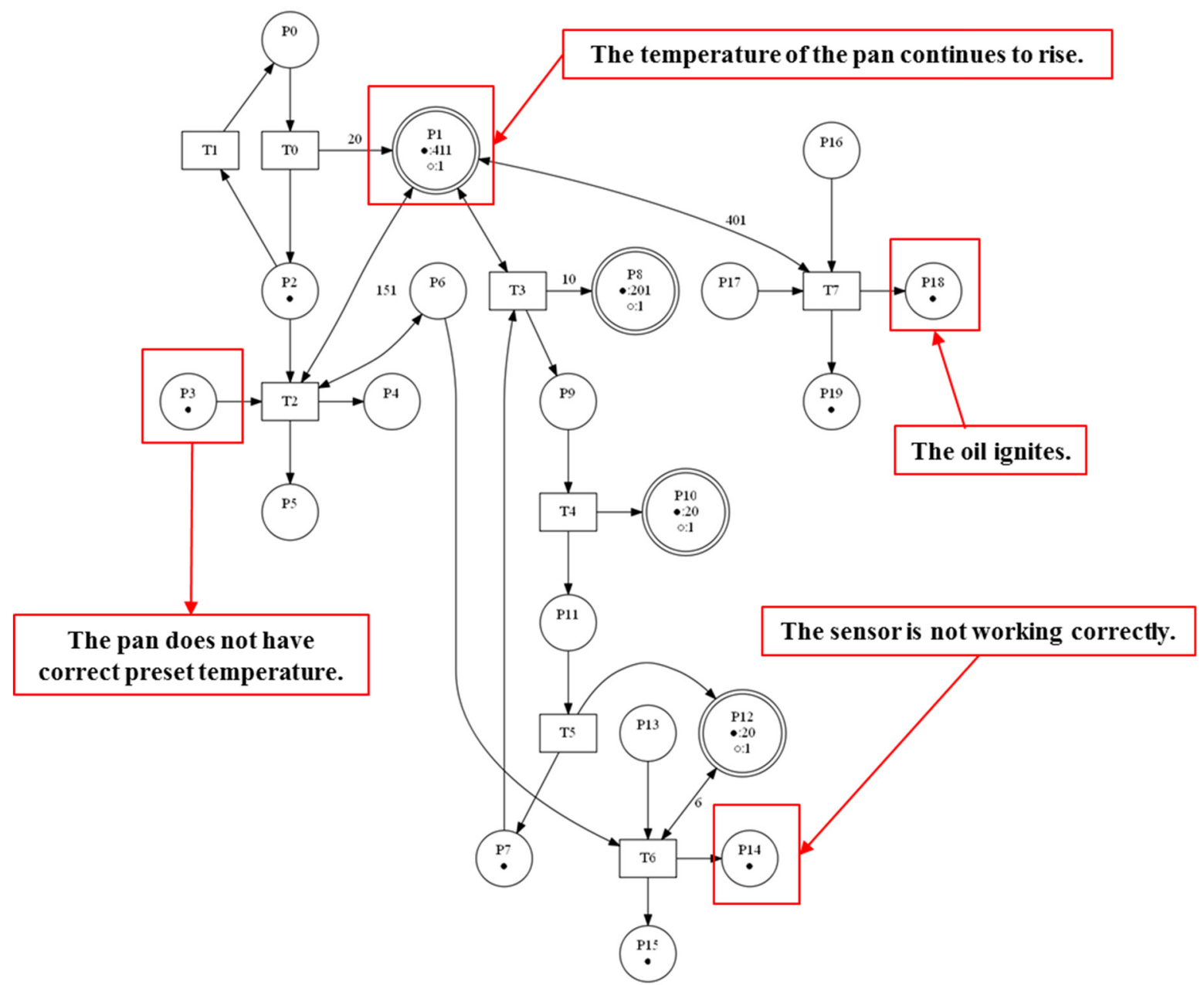

Fig. 18 Integrated model of IH cooking heater of the final state. As the sensor is not working correctly, the temperature of the pan continues to rise, and the oil ignites. Thus, the failure concerning to specification can be detect by the system. It is possible to urge the designer to modify the design plan by showing this result.

\section{5. 結 言}

本稿では，使い方を考慮した製品設計案の機能的不具合の検出手法を，仕様に関する不具合の検出にも適用で きるようにするための拡張について論じた，黒・白トークンで状態の属性值を表現し，黒・白アークと黒・白抑 止アークを用いて, 状態の属性值の加減や状態の属性值をトランジションの発火条件に設定することで, ペトリ ネットによる状態, 挙動, 事象因果の定量的表現を可能にした. また, アークの重みを動的に変化させることで, 状態の属性值によって変化する挙動・事象因果の表現も可能とした. そして, 鍋の下にマットを敷いて IH クッ キングヒーターを使用するという例に提案手法を適用し，仕様に関する不具合が検出できることを確認した.

本稿の提案手法は，定性的な分析を行う従来手法を定量的な分析にも適用できるようにしたものであるため, 定性的な情報と定量的な情報とが混在しているモデルに対して，定性的な不具合と定量的な不具合の双方の検出 が可能である，例えば，まだ製品の詳細が決まっていない部分は定性モデルで作成し，詳細に決まっている，も しくは不具合検出の精度を高めたい部分を定量モデルで表現した場合でも不具合検出が可能になると期待できる. 不具合検出の際に, 定量的な状態だけではなく定性的な状態を含むため, 一般には分析結果の精度には限界があ るが，不具合の可能性を提示することに重きを置けば十分な効果が見込めると考えられる.

提案手法を適用するにあたって, 事象因果は使い方によって変化するため, 使い方の設定の都度, 事象因果乇 デルを作成する必要があるが，これは合理的ではない，このため，実用の観点からこの手法では，物理事象群の 因果関係についてのデータベースが予め構築されており，それを用いて事象因果モデルを自動生成して，不具合 の検出を行うことが前提となっている. この事象因果データベースをどのように構築するかが，今後の課題とし て挙げられる. 


\section{文献}

平岡洋二，山本克成, 物理量次元インデクシングによる知識マネジメントの製品設計への応用（FTA 支援ツール の開発と適応事例），日本機械学会論文集 C 編, Vol.77, No.784 (2011), pp.4672-4681.

Lee, W. S., Grosh, D. L., Tillman, F. A. and Lie, C. H., Fault tree analysis, methods, and applications a review, IEEE Transactions on Reliability, Vol.R-34, No.3 (1985), pp.194-203.

Morinaga, E., Akasaka, T., Wakamatu, H., Arai, E. and Abiru, H., Framework for functional verification in product design considering ways and situations of use, Transactions of the Institute of Systems, Control and Information Engineers, Vol.28, No.3 (2015a), pp.116-122.

Morinaga, E., Wakamatu, H., Abiru, H. and Arai, E., A behavior modeling method for functional verification of product considering ways of use, Proceedings of International Conference on Design and Concurrent Engineering 2015, (2015b) Paper No. 9.

Morinaga, E., Wakamatu, H., Arai, E. and Abiru, H., Behavior analysis method for product design support, Proceedings of International Conference on Electronics Packaging 2014 (2014), pp.736-739.

森永英二, 若松栄史, 目賀眞周, 荒井栄司, センサ搭載製品の設計のための使い方を考慮した機能検証法, システ ム制御情報学会論文誌, Vol.29, No.10 (2016), pp.441-447.

村上存, 菊池洋輔, 物理量次元インデクシングに基づく故障木解析の知識マネジメント, 日本機械学会論文集 $\mathrm{C}$ 編, Vol.75, No.756 (2009) pp.2171-2180.

独立行政法人国民生活センター，available from <http://www.kokusen.go.jp/news/data/n-20130221_1.html>，(参照日 2017 年 2 月 1 日).

Rausand, M. and Oien, K., The basic concepts of failure analysis, Reliability Engineering \& System Safety, Vol.53, No.1 (1996), pp.73-83.

冨山哲男, 吉川弘之, 機能論構築を目指して一設計の立場から一, 精密工学会誌, Vol.56, No.6 (1990), pp.964-968.

\section{References}

Hiraoka, Y. and Yamamoto, K., Application of knowledge management based on quantity dimension indexing on the product design activity (development of the support tool for FTA and the case study in JATCO), Transactions of the Japan Society of Mechanical Engineers, Series C, Vol.77, No.784 (2011), pp.4672-4681 (in Japanese).

Lee, W. S., Grosh, D. L., Tillman, F. A. and Lie, C. H., Fault tree analysis, methods, and applications a review, IEEE Transactions on Reliability, IEEE Transactions on Reliability, Vol.R-34, No.3 (1985), pp.194-203.

Morinaga, E., Akasaka, T., Wakamatu, H., Arai, E. and Abiru, H., Framework for functional verification in product design considering ways and situations of use, Transactions of the Institute of Systems, Control and Information Engineers, Vol.28, No.3 (2015a), pp.116-122.

Morinaga, E., Wakamatu, H., Abiru, H. and Arai, E., A behavior modeling method for functional verification of product considering ways of use, Proceedings of International Conference on Design and Concurrent Engineering 2015, (2015b) Paper No. 9.

Morinaga, E., Wakamatu, H., Arai, E. and Abiru, H., Behavior analysis method for product design support, Proceedings of International Conference on Electronics Packaging 2014 (2014), pp.736-739.

Morinaga, E., Wakamatu, H., Mega, M. and Arai, E., Functional verification method considering ways of use for design of products with sensors, Transactions of the Institute of Systems Control and Information Engineers, Vol.29, No.10 (2016), pp.441-447 (in Japanese).

Murakami, T. and Kikuchi, Y., Knowledge management for fault tree analysis based on quantity dimension indexing, Transactions of the Japan Society of Mechanical Engineers, Series C, Vol.75, No.756 (2009), pp.2171-2180 (in Japanese).

National Consumer Affairs Center of Japan, available from <http://www.kokusen.go.jp/news/data/n-20130221_1.html>, (accessed on 1 February, 2017) (in Japanese).

Rausand, M. and Oien, K., The basic concepts of failure analysis, Reliability Engineering \& System Safety, Vol.53, No.1 (1996), pp.73-83.

Tomiyama, T. and Yoshikawa, H., Towards a theory of function : design perspective, Transactions of the Japan Society of Precision Engineering, Vol.56, No.6 (1990), pp.964-968 (in Japanese). 